Miomir Korać,

Arheološki institut Beograd

Vojislav Stojanović,

Arheološki institut Beograd

Nemanja Mrđić

Arheološki institut Beograd

904"652":550.837.7(497.11)

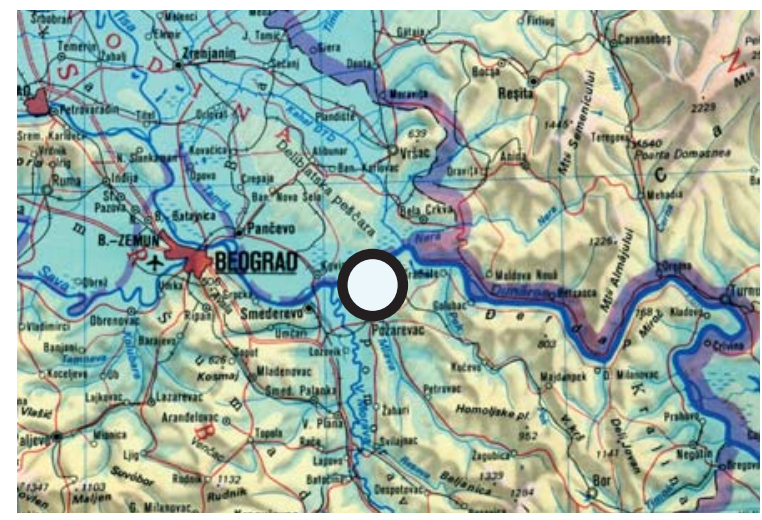

Viminacium, Stari Kostolac, Srbija

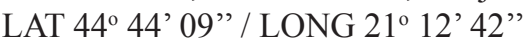

\title{
PRIMENA GEORADARA U ISTRAŽIVANJIMA RIMSKOG AKVEDUKTA NA VIMINACIJUMU
}

\begin{abstract}
ABSTRAKT
Velikim arheološkim istraživanjima akvedukta na Viminacijumu prethodila su sistematska geofizička snimanja zone ugrožene radovima površinskog kopa ,Drmno “. Korišćenjem georadara (GPR - Ground Penetrating Radar) utvrđena je tačna trasa gravitacionih kanala. Na osnovu dobijenih rezultata iskopavanje je fokusirano na arhitektonske ostatke čime se uštedelo na vremenu, suzila potrebna širina iskopa i izbegle prazne sonde. Pošto se na trasi akvedukta u zavisnosti od više faktora prave krivine one su precizno locirane.
\end{abstract}

KlJuČne rečl: arheologiJa, aKVedukt, Viminacijum, georadar, GPR, Geofizika, MULTIDISCIPLINARNA ISTRAŽIVANJA.

Početkom marta 2003. godine, bager za uklanjanje jalovine na površinskom kopu uglja „Drmno“ na lokalitetu Stig, presekao je antičke zidove. ${ }^{1}$ Arheološka ekipa koja je izvršila primarno rekognosciranje terena, utvrdila je da se radi o gravitacionom kanalu rimskog akvedukta. Obustavljen je rad mehanizacije i preduzeti su hitni zaštitni radovi u zoni gde su locirani ostaci. ${ }^{2}$ Pošto je prostor koji je ugrožen radom kopa tokom 2003. godine površine preko 20 hektara, preduzeta su obimna i sistematska geofizička snimanja terena da bi se otkrili arheološki objekti. Na taj način

1. Gravitacioni kanali otkriveni su na oko $3200 \mathrm{~m}$ od istočne kapije kastruma u pravcu jugoistoka.

2. Blagojević, Stojković-Pavelka. 2004.

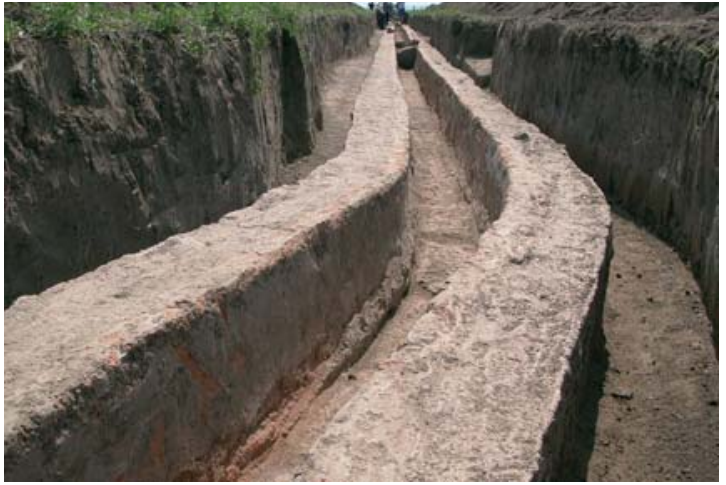

Slika 1. Jedna od krivina gravitacionog kanala akvedukta 1. tokom iskopavanja (foto M. Korać)

ubrzana su iskopavanja koja su se koncentrisala na konkretne arhitektonske ostatke. Izbeglo se kopanje praznih sondi, a sistem vodosnabdevanja 


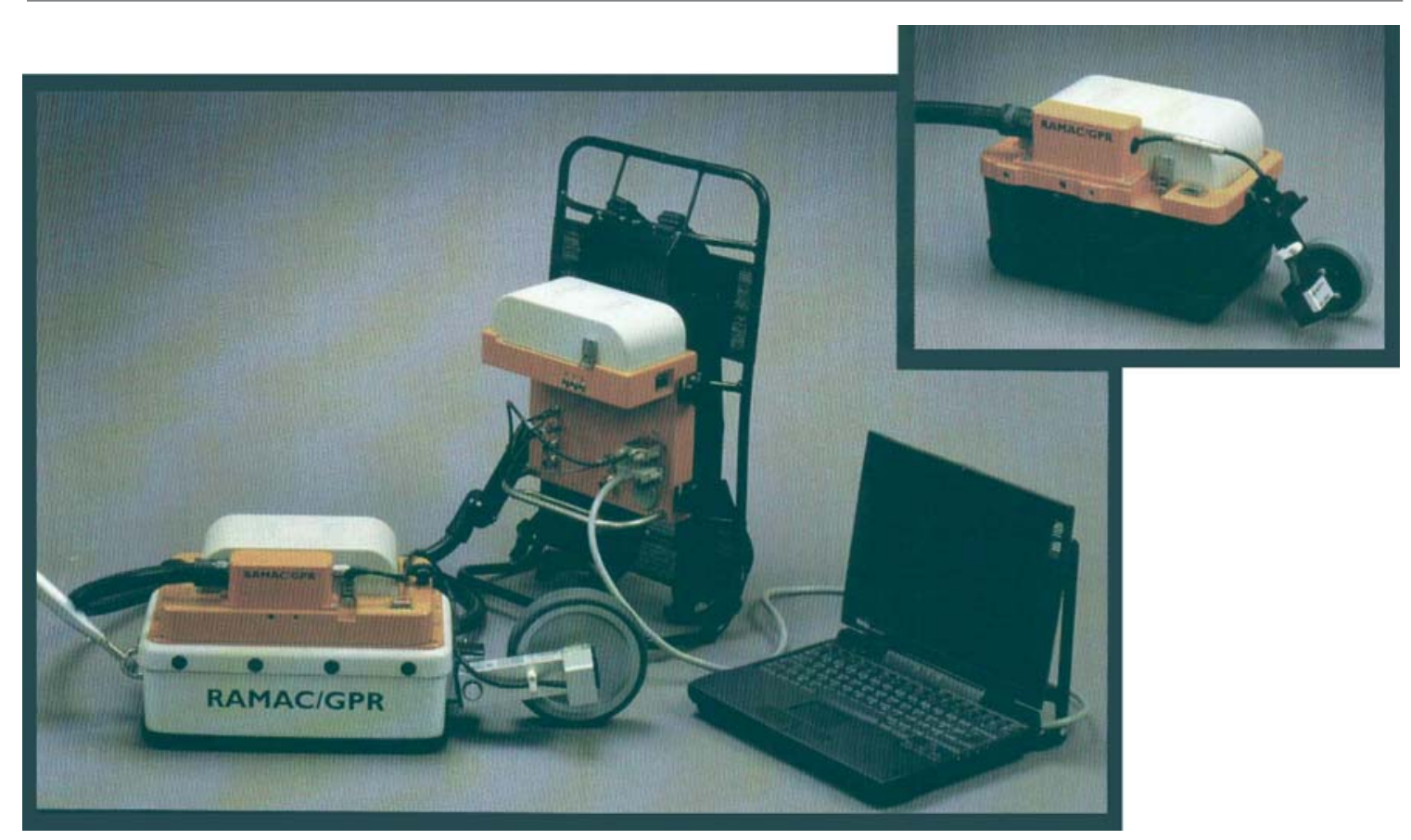

Slika 2. Georadarski sistem RAMAC/GPR (antena $500 \mathrm{Mhz}$, prijemnik i notebook računar). Proizvođač je firma MalaGeoscience (Švedska)

je praćen u kontinuiranom iskopu od više stotina metara. Arheološkim rekognosciranjem praćenim GPS lociranjem kartirana je šira oblast. Sistematsko iskopavanje je vršeno na celom prostoru gde je potvrđena trasa gravitacionih kanala. Ukupna dužina iskopa je preko 1.150 metara. Ovi radovi vršeni su istovremeno tokom više meseci sistematskih istraživanja. ${ }^{1}$

Sistem vodosnabdevanja Viminacijuma biće predmet posebne studije. U ovom radu prezentovaćemo samo konkretne rezultate geofizičkih merenja i način na koji su oni primenjeni prilikom arheoloških iskopavanja.

\section{METODOLOGIJA PRIKUPLJANJA I OBRADE GEOFIZIČKIH PODATAKA}

Akvizicija podataka je vršena georadarskim sistemom RAMAC CUII (MALA Geoscience) sa antenom frekvencije od 250 i $500 \mathrm{MHz}$ (sl. 2). Ukupna istražena površina je približno 2 ha. Ova površina je podeljena na 36 istražnih polja dimenzija $20 \times 20,20 \times 30$ i $25 \times 30 \mathrm{~m}$. U okviru svakog polja mereno je po paralelnim profilima na međusobnom rastojanju od $0,5 \mathrm{~m}$. Rezolucija snimanja je takva da se duž profila dobija podatak na svaka $2 \mathrm{~cm}$. Terenska sredstva kao merne trake, kočići, itd., napravljeni su od materijala koji ne utiču na kvalitet merenja ili dobijenih podataka. Traka po kojoj se antena kretala (sl. 3) markirana je na svaka $2 \mathrm{~m}$ kako bi se kasnije u obradi smanjila greška interpolacije. Podaci su tokom merenja sačuvani u softveru za prikupljanje podataka RAMAC Groundvision-u, a zatim radi dalje obrade $\mathrm{i}$ interpretacije unošeni u softverski paket ReflexW. Rezultati istraživanja su prikazani u vidu horizontalnih dubinskih preseka, koji su nastali softverskim spajanjem svih profila jednog istražnog polja. Istražna polja su georeferencirana kako bi se što bolje izvršilo postavljanje arheoloških sondi. Postavljanjem istražnih polja na aerosnimak i topografsku kartu kao podloge dobijen je situacioni plan.

1. Svi podaci pomenuti u ovom članku preuzeti su iz terenske dokumentacije iskopavanja Viminacijuma osim ukoliko nije drugačije naglašeno. 


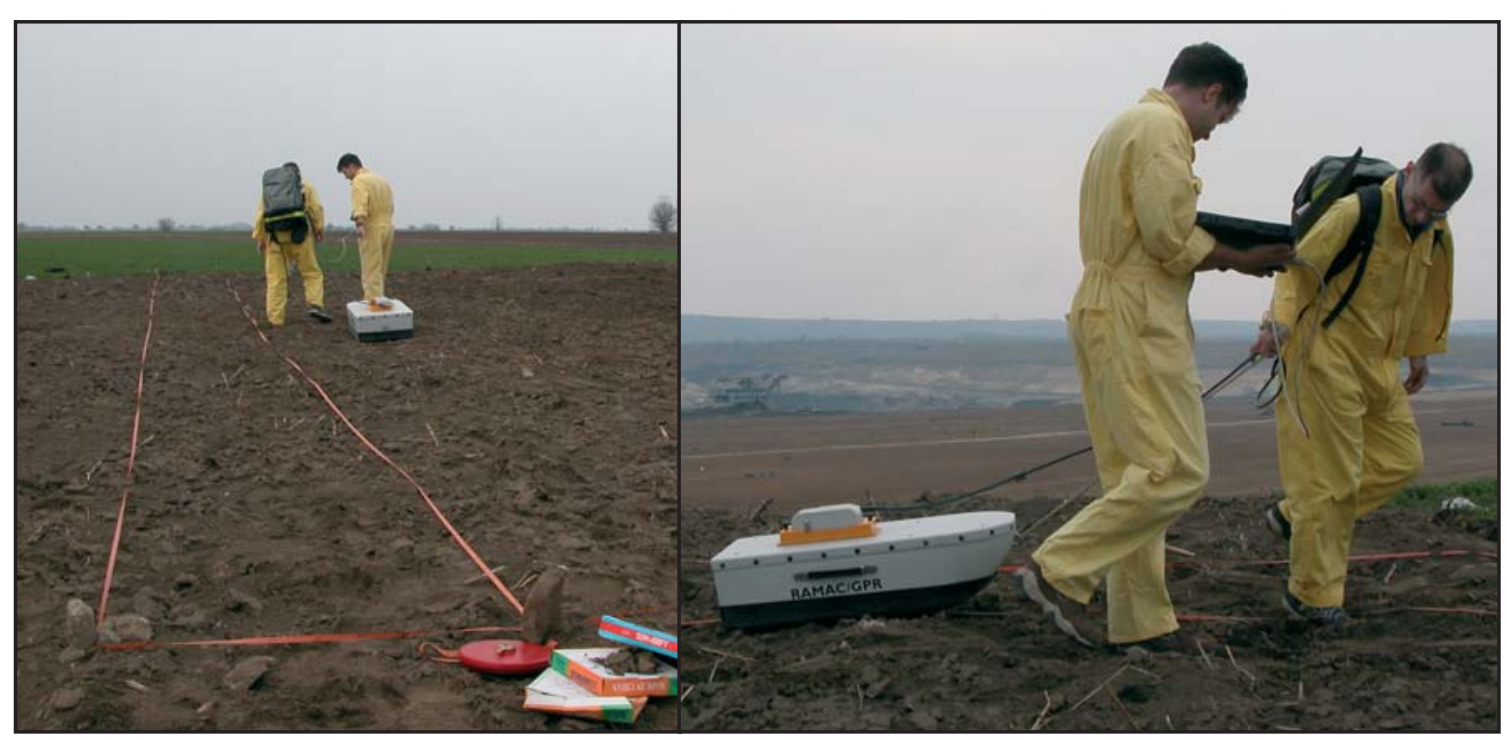

Slika 3. Georadarska merenja na trasi akvedukta tokom proleća 2003. godine

\section{INTERPRETACIJA GEOFIZIČKIH REZULTATA}

Interpretacija georadarskih podataka se zasniva na uočavanju razlike elektromagnetskih karakteristika materijala. Akvedukt je sagrađen pretežno od kamena, a nalazi se u glinovitoj zemlji. Kako ova dva materijala imaju različite elektromagnetske parametre, anomaliju koja predstavlja akvedukt jasno uočavamo na slici 4. Na ovoj slici prikazan je karakterističan georadarski profil na kome je na horizontalnoj osi prikazana pozicija, a na desnoj vertikalnoj osi dubinski zahvat. Profil je svojim pružanjem presekao trasu akvedukta. ${ }^{2}$ Softverskom obradom

2. Kad god je bilo moguće pretpostaviti pravac pružanja kanala profili su snimani poprečno u odnosu na njihovu se ovakvi profili spajaju u polja koja se prikazuju po dubinskim presecima. Na slici 10. može se uočiti položaj nekoliko georeferenciranih polja (B, C, D, F i G) prikazanih na dubinskom preseku od $45 \mathrm{~cm}$ i polje $\mathrm{K}$ na dubinskom preseku od 70 cm kao i samo pružanje oba akvedukta koja su u ovom delu subparalelna. Polje $C$ je na slici 8 prikazano u vidu 25 dubinskih nivoa. Gornji levi ugao predstavlja najplići presek (osnova 1), a dubina preseka raste naniže tako da slika u donjem desnom uglu predstavlja i najdublji presek (osnova 25). Ovakav, stratigrafski način prikaza, omogućava procenu očuvanosti na određenoj dubini. Najinteresantniji nivoi polja $\mathrm{C}$ su 3D modelovani i prikazani na slici 9 , gde se može

trasu. Na taj način se na svakom profilu uočava kanal, što ne bi bio slučaj kada bi se profili snimali podužno

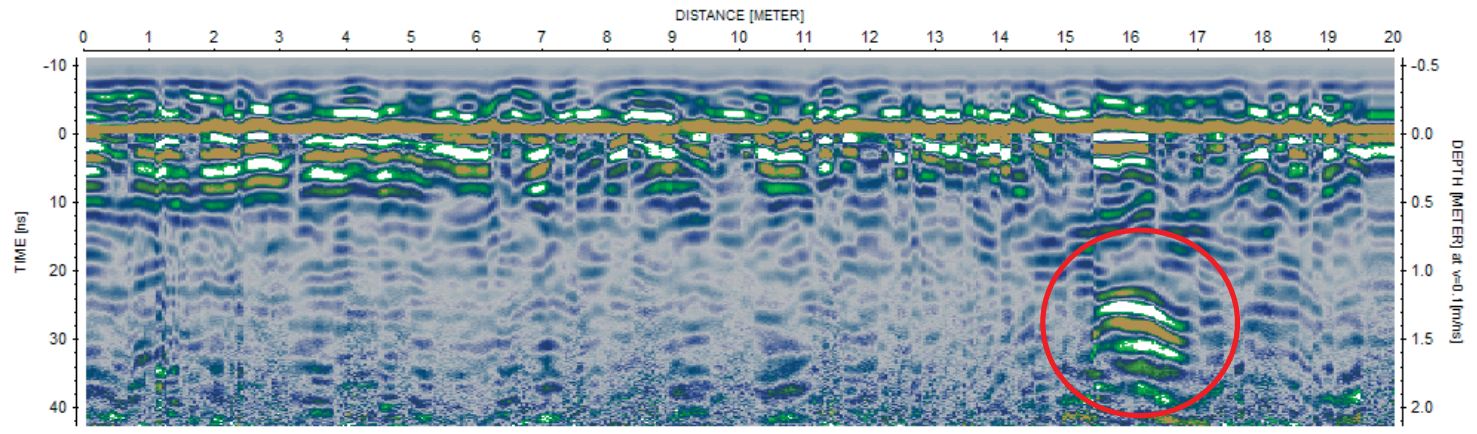

Slika 4. Trasa akvedukta 1. Georadarski profil postavljen poprečno na trasu akvedukta. Polje A, profil 2 dužine $20 \mathrm{~m}$. Obeležen je gravitacioni kanal akvedukta 


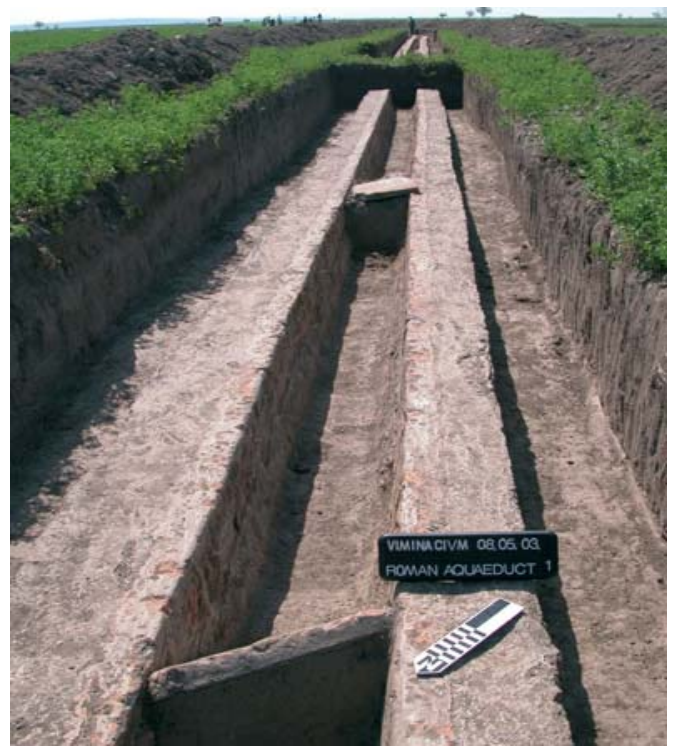

Slika 5. Očuvani gravitacioni kanal (foto M. Korać)

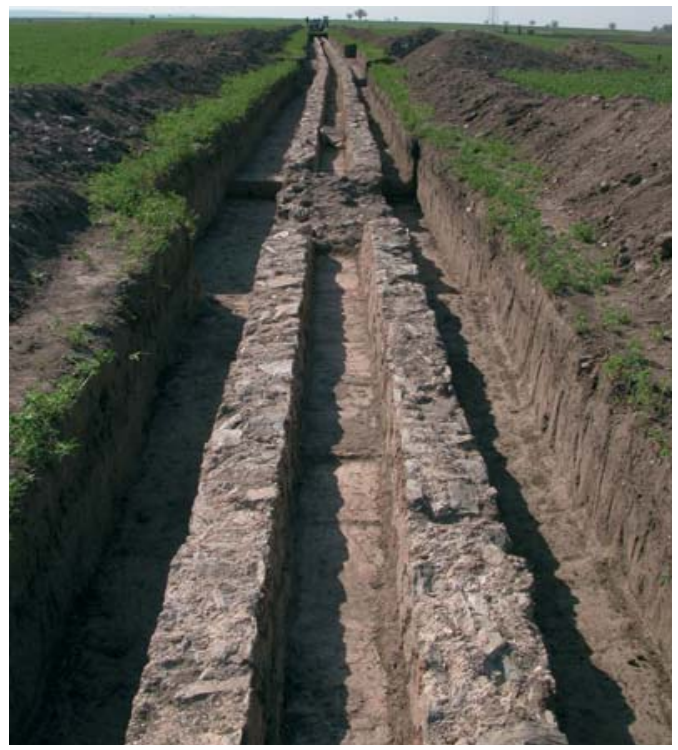

Slika 6. Delimično očuvani gravitacioni kanal (foto M. Korać)

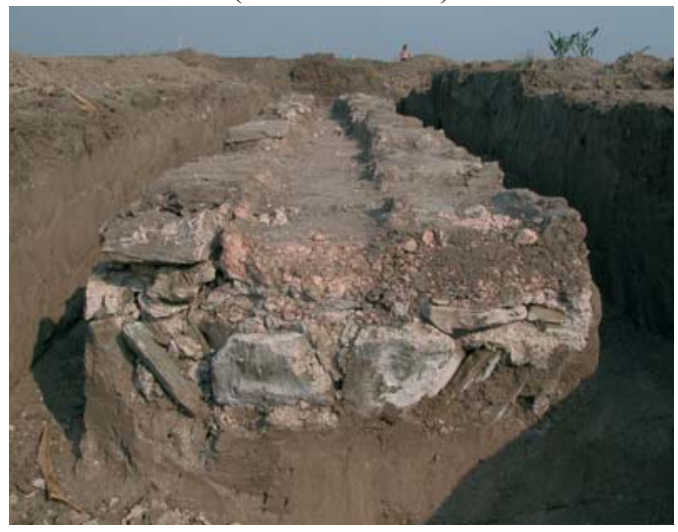

Slika 7. Temeljna zona gravitacionog kanala (foto M. Korać) zaključiti da se akvedukt javlja već na oko $50 \mathrm{~cm}$, dok je na $80 \mathrm{~cm}$ najbolje očuvan. Treba naglasiti da je polje $\mathrm{C}$ uzeto samo kao metodološki primer obrade i interpretacije georadarske metode i da je isti postupak primenjen na svih 36 polja.

Analiza i arheološka interpretacija vršeni su na osnovu tri vrste grafičkih prikaza dobijenih georadarskim merenjem:

- vertikalni preseci - profili (sl. 4 - Prikaz profila 2 u polju A). Pružaju uvid u presek arhitektonskih ostataka kako po dužini, tako i po dubini, na kojoj se nalaze.

- osnove - horizontalni preseci, u obradi se dalje razlažu na preseke po dubinama $($ sl. 8,10$)$. Pružaju uvid u gabarite objekta. Georeferencirani horizontalni preseci se unose u GIS bazu podataka i daju jasan situacioni plan. Otkrivene strukture je na taj način moguće sa najvećom preciznošću locirati na terenu.

- 3D modeli (sl. 9). Objekat se može posmatrati u prostoru iz svih uglova čime je omogućena preciznija interpretacija i uvid u očuvanost i oblik oštećenja arhitektonskih ostataka.

Arheološke sonde postavljene su na osnovu rezultata geofizičkih merenja. U svim sondama otkriveni su zidovi gravitacionih kanala akvedukata. Pošto je zona istraživanja obuhvatila širi prostor u odnosu na pronađeni kanal, ubrzo se pokazalo da nije u pitanju jedan već dva akvedukta koji su skoro paralalelni.

Akvedukt 1, otkriven je na dubini od 0,45 m (sl. 1). Širok je 1 metar, sa visinom kanala od $0,5 \mathrm{~m}$. Šut koji se prati na površini razvučen je oranjem u širini i do 10 metara. Na osnovu podataka iz izvora znamo da je u zoni neposredno uz kanale bila zabranjena gradnja. ${ }^{1}$ Ovi navodi su arheološkim istraživanjima u blizini Viminacijumu potvrđeni. Na razdaljini od više desetina metara nije konstatovan nijedan objekat osim drugog kanala.

1. Frontin „O akveduktima Rima“ (Sextus Iulius Frontinus - De aqueductu urbis Romae), Vitruvije „O arhitekturi” (Marcus Vitruvius Pollio - De architectura), Ilakovac 1982. 
$\mathrm{Na}$ razdaljini od svega dvadesetak metara, otkriven je gravitacioni kanal drugog akvedukta. Nalazi se na dubini od $0,7 \mathrm{~m}$. Princip gradnje je isti. Razlikuju se samo u tome što je akvedukt 2. nemarnije zidan.

Prateći konfiguraciju terena oni se međusobno udaljavaju ili približavaju, ali su celom trasom relativno blizu jedan drugog.

Kvalitet rezultata je u direktnoj zavisnosti od očuvanosti gravitacionih kanala koji su mereni. Oba akvedukta su veoma različito očuvana. Građevinski materijal rimskog Viminacijuma je vekovima intenzivno korišćen za podizanje Smederevske tvrđave, kuća po Požarevcu i okolnim selima. To je uslovilo da se danas na površini ne vide arhitektonski ostaci. Akvedukti su doživeli istu sudbinu kao i ostale građevine. ${ }^{2}$

Akvedukti su građeni od kamena ${ }^{3}$ i opeke vezanih krečnim malterom. Unutrašnjost kanala je malterisana hidrostatičkim malterom ${ }^{4}$. Bili su pokriveni horizontalno postavljenim opekama.

$\mathrm{Na}$ celoj trasi konstatovani su samo ostaci podzemnih gravitacionih kanala. ${ }^{5}$ Neki njihovi delovi očuvani su skoro u celosti. Nedostaju samo opeke kojima je bio pokriven (sl. 5). S druge strane ima delova, koji su znatno duži, od kojih je ostala samo temeljna zona (sl. 7). U pojedinim zonama ostaci akvedukata se mogu pratiti samo u negativu - čak je i kamen iz temeljne zone izvađen za građevinski materijal.

Delovi akvedukata koji su dobro očuvani

2. Feliks Kanic, (Kanic, 1985) prilikom poseta Viminacijumu, krajem XIX veka, pominje ostatke vodovoda i rezervoara. Danas se od toga ništa ne vidi na površini. Njegov pomen o 4000 kola kamena i drugog građevinskog materijala na pijaci u Požarevcu je najbolje svedočanstvo o obimu destrukcije arheoloških ostataka.

3. Natrijsko-albitski škriljac iz majdana u Ramu, u žargonu poznat među lokalnim stanovništvom kao „kamen zelenac"

4. Radi se o krečnom malteru sa dodatkom mrvljene opeke, koji je vodonepropustan i sposoban da izdrži jak pritisak. Korišćen je kao oplata - hidroizolator u bazenima i kanalima.

5. Feliks Kanic u svom opisu Viminacijuma izričito pominje da je video akvedukt i rezervoare. Nikakav precizniji podatak nije naveden. Ostaje nejasno da li je blizu grada deo kanala bio nadzeman. jasno se ocrtavaju na snimcima. Na tim mestima ima i manje šuta pa nema „smetnji“ koje bi davale nejasan odraz. Na onim mestima gde je akvedukt lošije očuvan (sl. 6) i gde je prilikom destrukcije formiran sloj šuta, odrazi nisu jasni. Šut prelazi preko kanala i na manjim dubinama ga maskira. Pošto je u pitanju isti materijal od koga je akvedukt izgrađen, šut daje isti odziv kao i sam kanal. Naravno u ovom slučaju se ne radi o kompaktnom odrazu. Ovo se u generalno označava kao „smetnja“. Na osnovu takvih razlika vrši se i dalja interpretacija. U dosta slučajeva rasuti materijal se ostavlja na snimku u cilju preciznije interpretacije. S druge strane on je često bio i jedini trag akvedukta čiji su zidovi povađeni pa se arheološki može pratiti samo u negativu. $\mathrm{Na}$ taj način se izbeglo iskopavanje uništenih delova, omogućeno je njegovo kartiranje, a pažnja je usmerena na očuvane delove kanala, koji su mogli kasnije biti izmešteni.

Razlike se najbolje izdvajaju analizom osnova po dubini, odnosno prema horizontalnim presecima. Jasno se uočava kako se sa povećanjem dubine šut gubi (S1. 8. horizontalni preseci 1-7), a izdvaja konstrukcija gravitacionog kanala (S1. 8. horizontalni preseci 8-19). Na većim dubinama gubi se i sam kanal (Sl. 8. horizontalni preseci 2023) i ostaje homogena sredina - dokaz da ispod nije bilo drugih konstrukcija (S1. 8. horizontalni preseci 24-25).

Pošto na trasi akvedukta postoje krivine (sl. 1), one su precizno locirane geofizičkim snimanjima. To je posebno važno za zone gde se šut ne javlja na površini, pa se krivine na drugi način ne mogu konstatovati.

\section{ZAKLJUČNO RAZMATRANJE}

Geofizička istraživanja su svojom brzinom i rezultatima uštedela vreme i fokusirala arheološka istraživanja na kontinuirana iskopavanja akvedukta. Interpretacijom anomalija koje se uočavaju na horizontalnim dubinskim presecima 
georadarskih polja, omogućeno je veoma lako praćenje pružanja gravitacionih kanala. Takođe je omogućen uvid u izgled arhitektonskih ostataka i sagledavanje daleko šire situacije od one koja je iskopavanjem istražena. Treba naglasiti i da su geofizička istraživanja potvrdila prethodno arheološko rekognosciranje.

\section{RESUME}

\section{Application of Ground Penetrating Radar (GPR) during excavations of Roman Aqueduct at Viminacium}

During 2003 a systematic protective excavations were undertaken to explore remains of the roman aqueducts at Viminacium. More than $1.150 \mathrm{~m}$ of both discovered aqueducts were excavated, and more than $4 \mathrm{~km}$ were mapped. Field survey with ground penetrating radar (GPR) preceded these excavations. Exact route of underground channels was established. According to GPR survey results trenches were positioned right over the channels. We present some of these results to show the way they were interpreted and what was discovered during excavations that followed. Both money and time were saved.
Translated by N. Mrđić

\section{BIBLIOGRAFIJA}

Blagojević, Pavelka 2004.

Blagojević, M. i Stojković-Pavelka, B. 2004. Viminacium - lokalitet „Stig“ - Akvedukt. Glasnik društva konzervatora Srbije 28: 62-64. Beograd: Zavod za zaštitu spomenika kulture.

\section{Ilakovac 1982}

Ilakovac, B. 1982. Rimski akvedukti na području Sjeverne Dalmacije. Zagreb: Arheološki muzej Zadar i Sveučilišna naklada Liber.

\section{Kanic 1985}

Kanic, F. 1985. Srbija zemlja i stanovništvo od rimskog doba do kraja XIX veka. Beograd: Srpska književna zadruga.

\section{Katanić, Gojković 1972}

Katanić, N. i Gojković, M. 1972. Građa za proučavanje starih kamenih mostova $i$ akvedukata $u$ Hrvatskoj. Beograd - Zagreb: Jugoslovenski institut za zaštitu spomenika kulture i Republički zavod za zaštitu spomenika kulture SR Hrvatske.

\section{Катанић, Гојковић 1961.}

Катанић, Н. и Гојковић, М. 1961. Грађа за проучавање старих камених мостова и акведуката y Србији, Македонији и Црној Гори. Београд: Савезни институт за заштиту споменика културе.

\section{IZVORI}

\section{Frontinus, Aqueducts of Rome}

Sextus Iulius Frontinus, 2003. Aqueducts of Rome, London: Loeb Classical Library

\section{Vitruvije, De architektura}

Marko Vitruvije Polio. 1952. De architectura - O arhitekturi. Sarajevo: Veselin Masleša. 

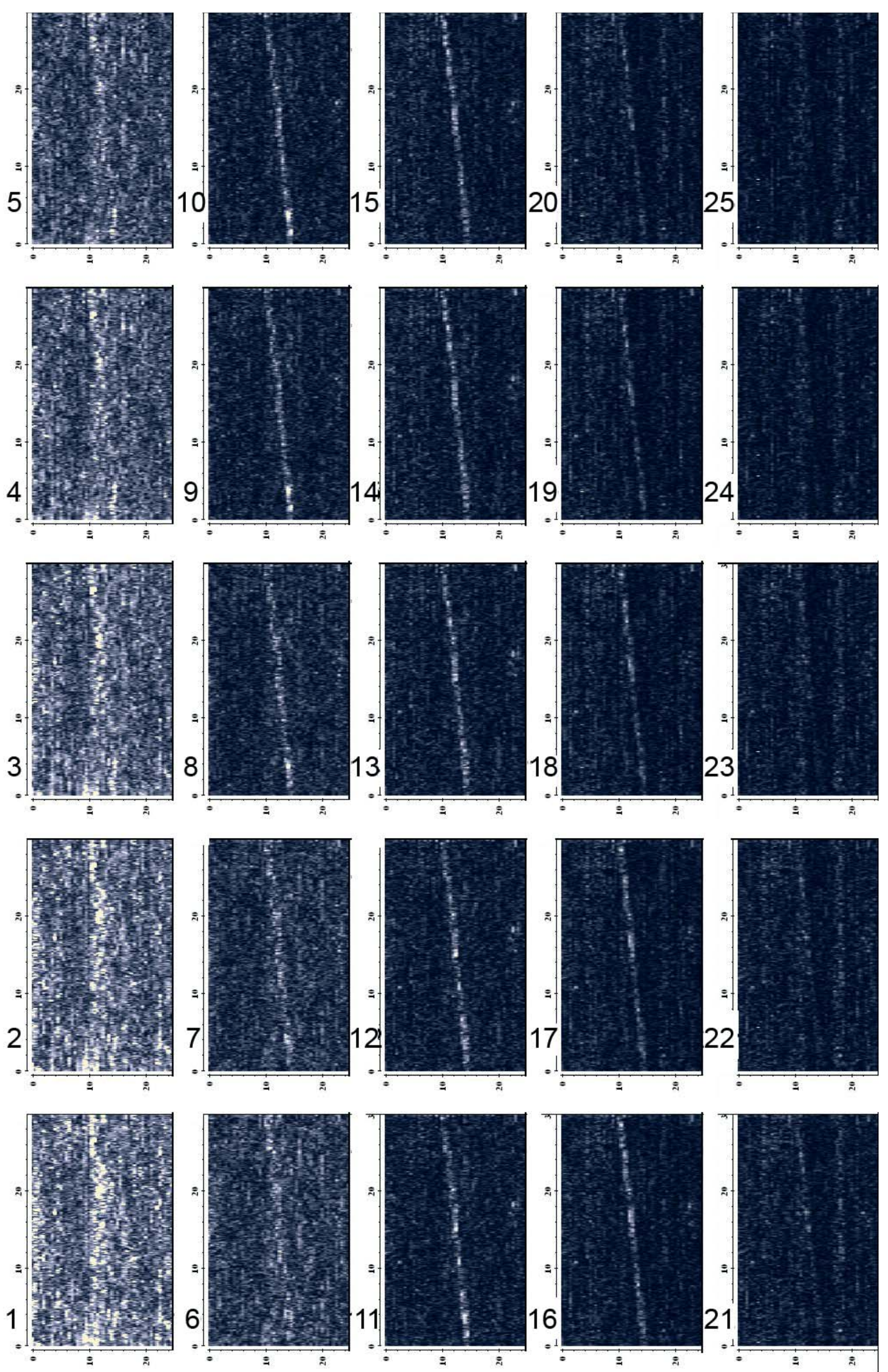

Slika 8. Akvedukt 1 - Horizontalni preseci polja $\mathrm{C}$ prema dubinama 


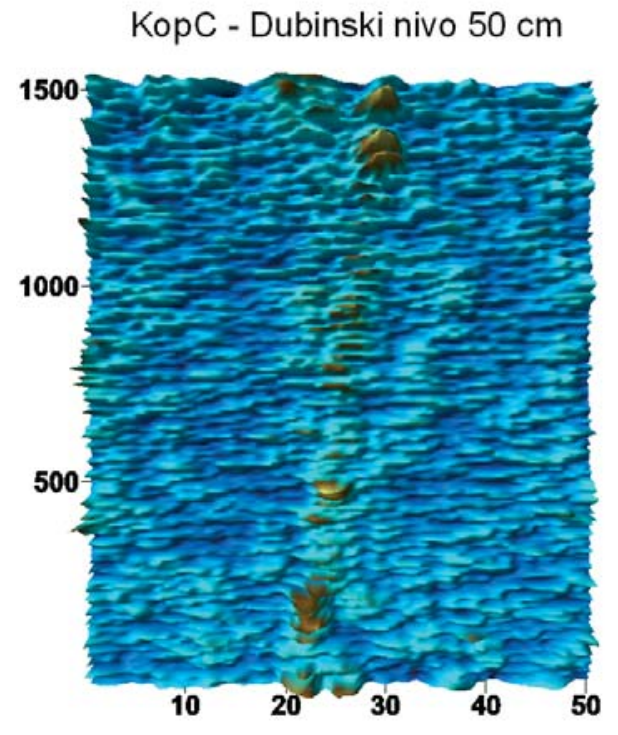

KopC - Dubinski nivo $70 \mathrm{~cm}$

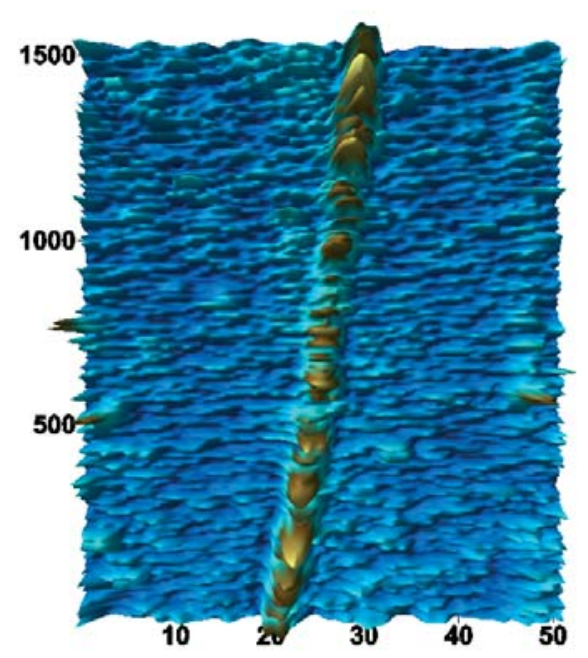

KopC - Dubinski nivo $60 \mathrm{~cm}$
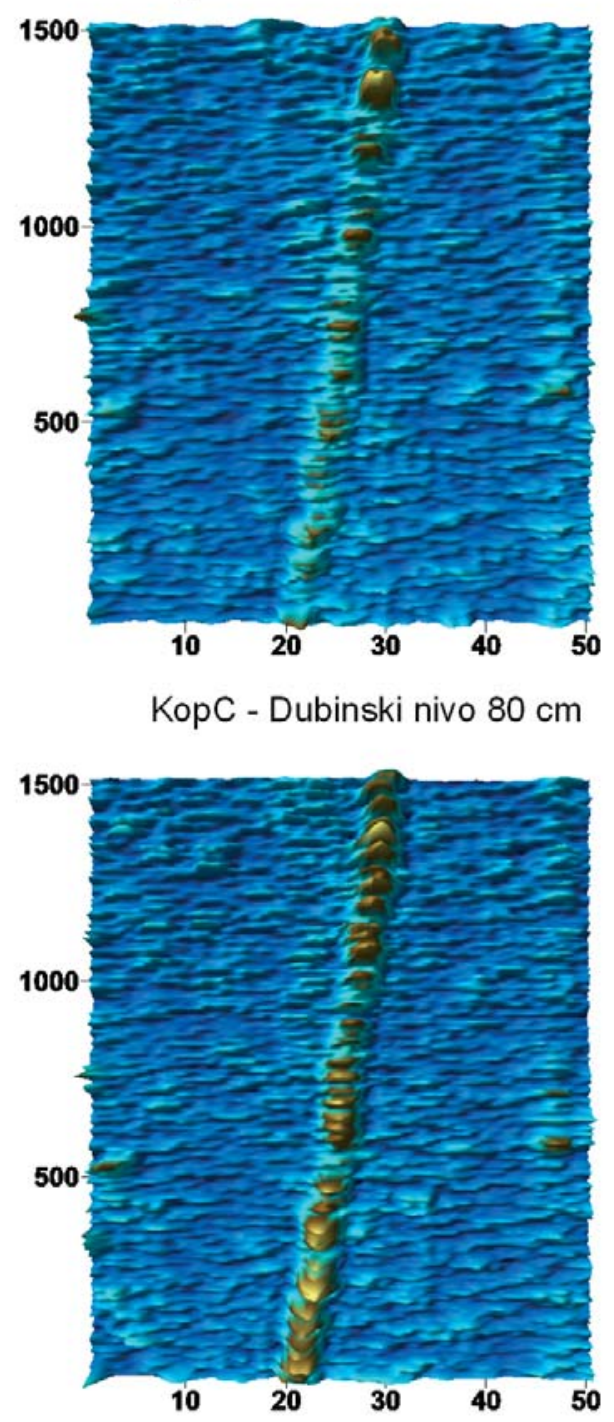

Slika 9. Prikaz rezultata na delu trase akvedukta u polju C, 3D modelovane osnove prema dubini: $50 \mathrm{~cm}, 60 \mathrm{~cm}, 70 \mathrm{~cm}, 80 \mathrm{~cm}$ 

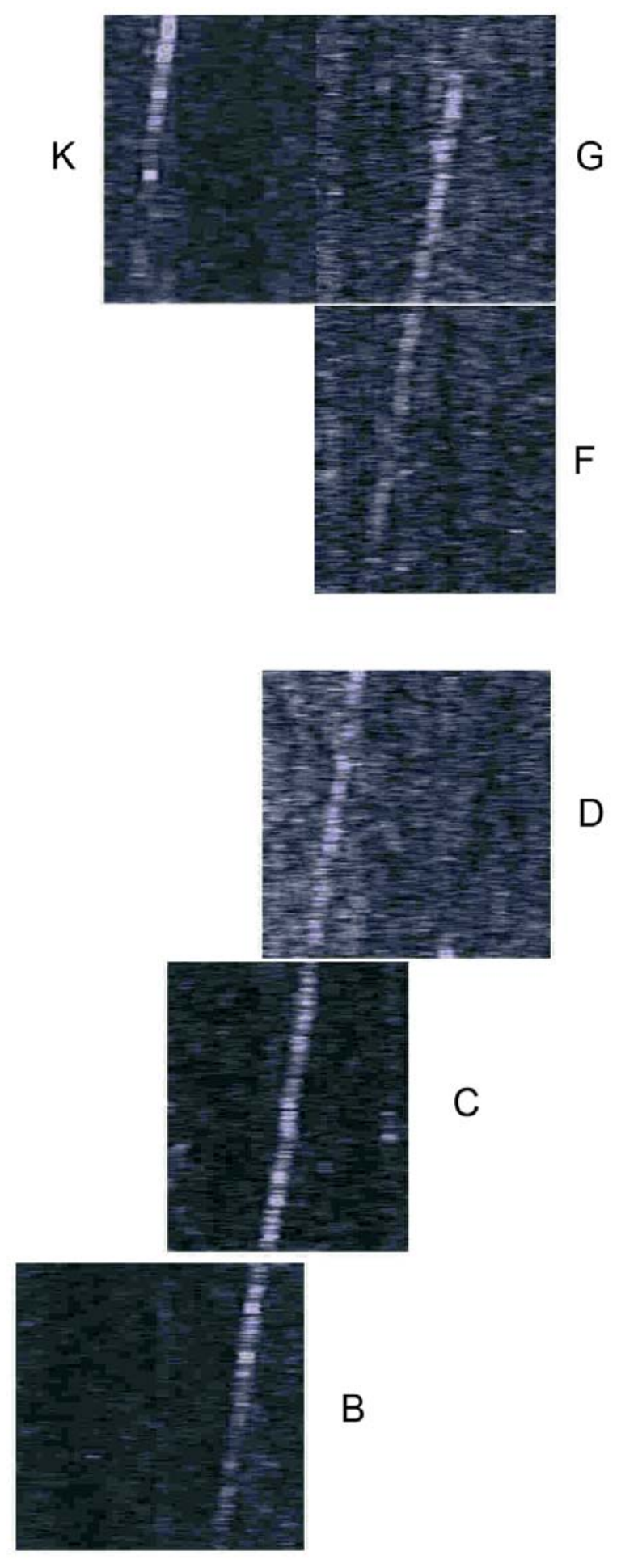

Slika 10. Georadarski snimak u osnovi - Vezana polja na delu trasa akvedukta B, C, D, F, G, K 


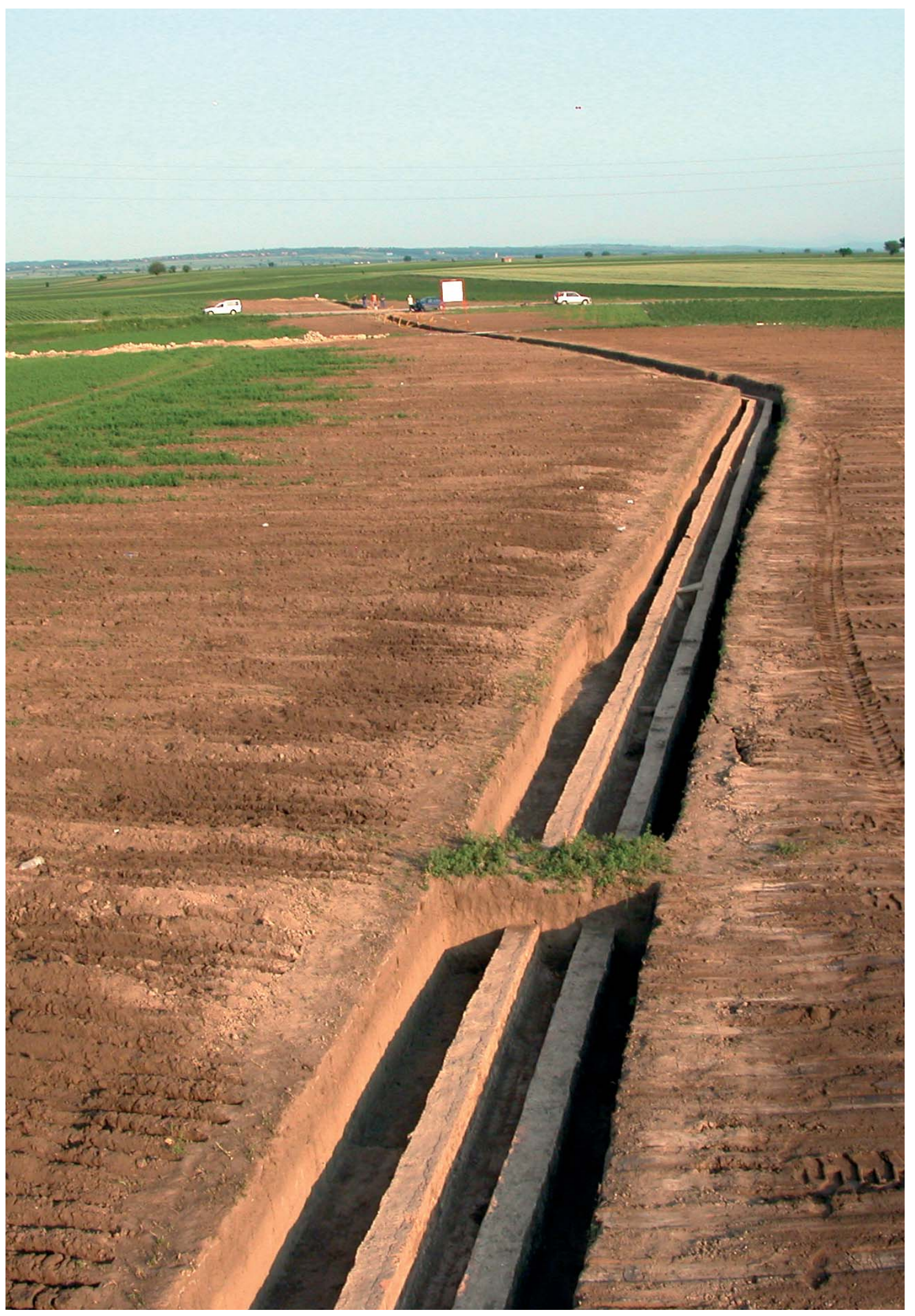

Slika 11 - Rimski akvedukt - pogled sa severa na gravitacioni kanal (foto M. Korać) 